\title{
The integration of indigenous knowledge into mine site rehabilitation and closure planning at Ok Tedi, Papua New Guinea
}

\author{
A.R. Butler NRA Environmental Consultants, Australia \\ I. Toh NRA Environmental Consultants, Australia \\ D. Wagambie Ok Tedi Mining Ltd, Papua New Guinea
}

\begin{abstract}
A critical element of the rehabilitation strategy for the Ok Tedi mine in Papua New Guinea (PNG) is the rehabilitation of the potentially acid forming dredge sand stockpiles at Bige on the banks of the Ok Tedi. Successful long-term mitigation of Acid Rock Drainage (ARD) involves placing a geochemical cover layer over the PAF waste and rehabilitation of the cover. Rehabilitation failure could lead to accelerated erosion, potentially compromising the integrity of ARD mitigation measures. Accordingly, the rehabilitation implemented at Bige must have a high certainty of being self-sustaining in the long-term.
\end{abstract}

Post closure, Ok Tedi Mining Ltd (OTML) will seek to relinquish mine lease areas and rehabilitated lands will form part of the land used by customary landholders for the acquisition of essential natural resources. Any attempt to impose a rehabilitation objective that fails to recognise the potential productivity of the postmine landscape or the land management techniques used by, and the long-term interests of, local landholders, risks failure. If the landholders reject the post mine land use options created by OTML and implement an alternative land-use, this may affect stockpile stability and compromise ARD mitigation measures.

The rehabilitation objectives for Bige needed to address the unique social as well as technical challenges of the site. In the affected area, agriculture is largely subsistence-based, using a system of long fallow (15-30 years or more) shifting cultivation. Traditional lands and forest resources are extensively used for providing food, fibre, medicine and shelter as well as cultural services. The post-mine plant community must therefore provide services that make it sufficiently valuable for affected communities to retain and manage sustainably.

In developing the rehabilitation strategy for Bige, information was gathered from local communities on goods and services provided by the surrounding forest, traditional vegetation and land management practices, and recognised cycles of clearing and forest regeneration.

This paper describes how the information provided by customary landholders was integrated into the rehabilitation strategy and completion criteria for this part of the Ok Tedi operation.

\section{Introduction}

\subsection{Project background}

The Ok Tedi mine, located in the Star Mountains of the Western Province of Papua New Guinea (PNG), began operations in 1984 and now predominantly produces copper concentrate.

Historically, the riverine disposal system annually discharged between 40 and 80 million tonnes (Mt) of tailings and waste rock into the headwaters of the Ok Tedi catchment. These inputs lead to aggradation of the river bed in the lower Ok Tedi and the Fly River, resulting in increased over bank flooding causing extensive forest dieback in the affected floodplains (OTML, 2007). 
Partly to address the then emerging dieback issue, river dredging commenced in 1998 in the lower Ok Tedi near the village of Bige about $100 \mathrm{~km}$ downstream of the mine (see Figure 1). Mine derived sediment is pumped to on-land stockpiles constructed on both banks of the Ok Tedi. The stockpile foot print will eventually cover approximately 1,000 ha.

Dredging has improved physical aspects in the Lower Ok Tedi and the Fly River, and has resulted in dieback recovery in the Lower Ok Tedi and fish habitat recovery in the vicinity of D'Albertis Junction. However, due to the increasing sulphur content in the mine waste, dredged material gradually became Potentially Acid Forming (PAF) and signs of Acid Rock Drainage (ARD) began to appear within a few years. To address this, OTML implemented the Mine Waste Tailings Project (MWTP) (OTML, 2006) that has decreased the sulphur content of the dredged waste so as to render it Non Acid Forming (NAF).

Long-term mitigation of ARD at Bige involves placing a NAF cover layer over the older PAF dredged waste and rehabilitation of the cover. If, however, erosion prematurely reduces the effectiveness of the NAF cover at Bige, the predicted reduction in loads may not be realised in full. Rehabilitation failure could lead to accelerated erosion, potentially compromising the integrity of ARD mitigation measures. It is therefore important that the rehabilitation strategy implemented at Bige has a high certainty of being self-sustaining in the long-term. The selection of an appropriate post-mine land use is a critical element of the strategy.

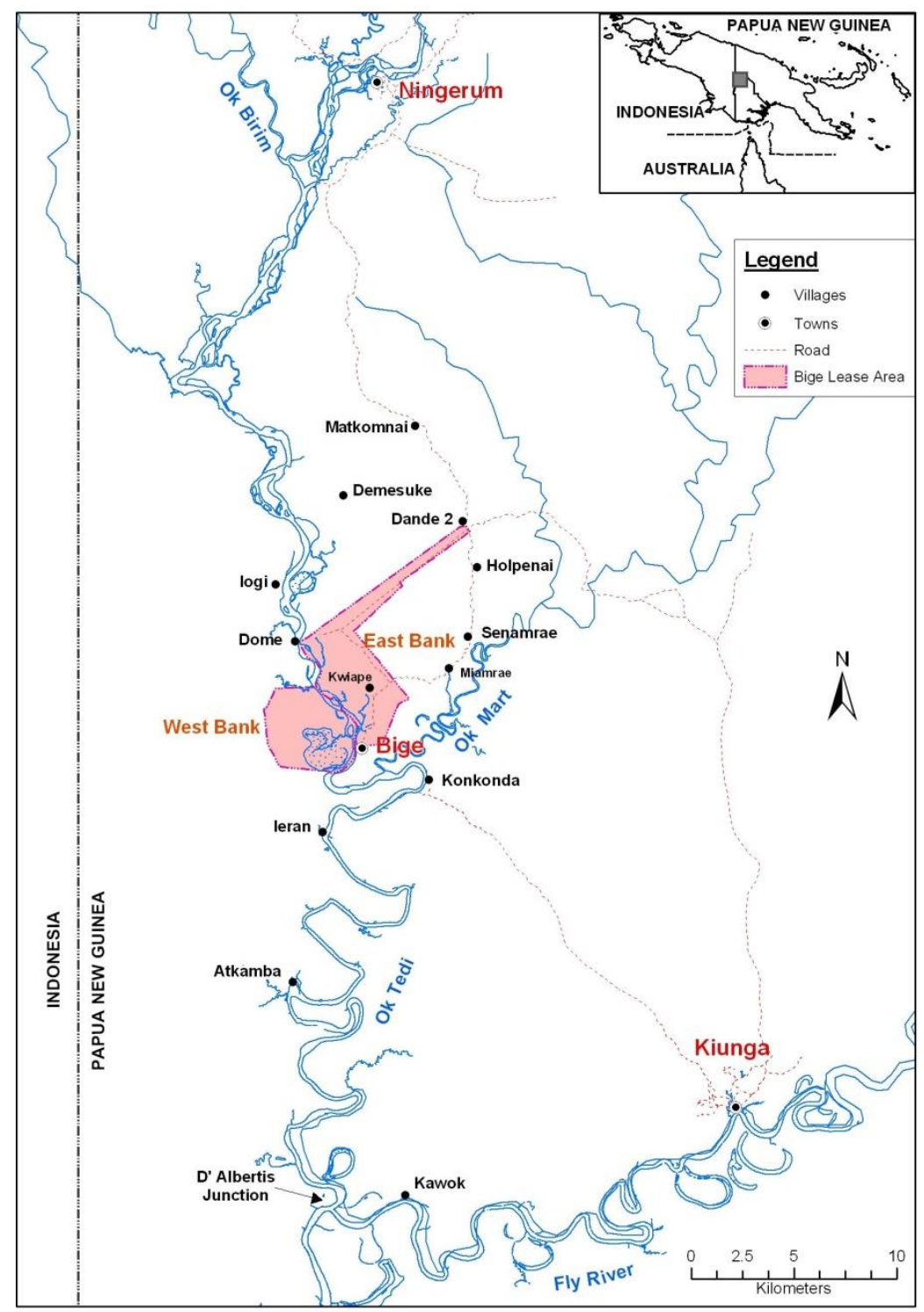

Figure 1 Project location 


\subsection{Social context}

Lamb and Gilmour (2003) warned that technical solutions rarely resolve complex natural resource management problems and that virtually all land-use planning involves people as well as the biophysical landscape. The post-mine land use must match the potential productivity of the post-mine landscape, the land management capacity of and the long-term interests of background landholders and, as highlighted by Smith $(2008,2009)$, be culturally appropriate. Limpitlaw et al. (2005) cite examples of post-mine management of rehabilitated land by farmers that conflicted with land capability and caused degradation, pollution and health and safety hazards. This must be avoided at Bige. If the landholders reject the postmine land use options developed for Bige and decide to implement an alternative land-use, this may affect stockpile stability and compromise ARD mitigation measures. The need to guard against this has been a driving force behind rehabilitation planning.

Low intensity shifting agriculture is practised at Bige and much of lowland Western Province. Gardens are cleared without burning and generally only one planting occurs in the cropping/clearing period, with little or no active soil fertility or agronomic management (Allen et al., 2002). Bourke and Harwood (2009) report that long fallows are still the most common management practice in the Western Province. Although mining derived income is important, affected communities around Bige still rely on forest resources and forest utilisation is still part of daily life (Jackson, 1998). The emergence or sustainability of alternative cash earning activities post closure in mine affected communities are uncertain (Jackson, 2002; Carr, 2010). The anticipated decline in household incomes post-closure will increase the reliance of affected communities on forest resources for meeting their everyday needs (Carr, 2010).

In this context, the post mining land use will be a form of lowland forest (NRA, 2009; OTML, 2009). The intent is for the land use to provide goods and services of known value to customary landholders while not preventing the adoption of alternative appropriate land uses should they become viable in the future.

\subsection{Project aims}

The project was initiated to provide input into rehabilitation and closure planning during the process of updating the OTML Mine Area Rehabilitation Plan (OTML, 2009).

The aim was to use indigenous knowledge to select species for rehabilitation use based on cultural values as well as ecological or silvicultural attributes to improve post-mine land use outcomes. The use of this knowledge was seen as a means of maximising the likelihood of acceptance of the proposed post mine land use by affected communities. The incorporation of the traditional knowledge of landholders in the planning process connected communities with the development of the rehabilitation strategy and implementation plan and ensured the development culturally appropriate completion criteria to validate the outcome (ICMM, 2008).

The project involved information gathering in three main areas of interest: ethnobotanical information on the goods and services provided by the surrounding forest (food, fibre, medicine, shelter, cultural and spiritual); indigenous vegetation and land management practices relevant to rehabilitation and indigenous knowledge of the cycles of clearing and forest regeneration. On this last point, it was hoped that local land managers might recognise soil or vegetation community attributes in regenerating forest that inferred a level of maturity or resilience and could thus be used as measures of rehabilitation progress or success. By using these attributes it was hoped that completion criteria could be developed that would be equally relevant to landholders as well as scientists or regulators. 


\section{$2 \quad$ Methods}

\subsection{Project area}

\subsubsection{Location}

Work was conducted in Bige, Kwiape, Miamrae and Senamrae, the four East Bank villages that have traditional lands in the areas affected by Bige stockpile construction ( $\mathrm{Dr}$ Monica Rau, 2008, pers. comm.). These villages are located between the Ok Tedi and the Ok Mart in the Western Province (WP) of PNG. They are located approximately $75 \mathrm{~km}$ south of Tabubil (the main administrative centre for OTML and the largest town in the WP), and approximately $30 \mathrm{~km}$ north-west of the port of Kiunga on the Fly River (the main local commercial centre and district capital) (see Figure 1). Work will extend to the West Bank communities (a different language group) in the future.

\subsubsection{Climate}

The climate is wet tropical with high rainfall throughout the year. Average annual rainfall of over 5,000 $\mathrm{mm}$ far exceeds annual evaporation of approximately $1,600 \mathrm{~mm}$. Temperatures show little variation throughout the year, with an annual average of approximately $26^{\circ} \mathrm{C}$.

\subsubsection{Landscape}

The study area is located in the floodplain of the Ok Tedi. It is largely flat (with only a $20 \mathrm{~m}$ fall between the site and the southern coast of PNG several hundred kilometres away) and has resulted in meandering rivers and extensive back swamps. Villages are located on low rises.

The soils of the area are either recent alluvial soils adjacent to waterways or strongly weathered acid soils with some clay translocation through the profile on higher ground. These latter soils have a low base saturation and are usually relatively infertile. The agricultural capacity of the land in the area is regarded as low or very low (Bourke and Harwood, 2009).

The material that will form the final cover is an alkaline $(\mathrm{pH} 8-8.5)$, fine to medium sand with low cation exchange capacity, low nutrient status and high total copper content. It contrasts with the acid (pH 4.5) silts and clays of the surrounding land.

\subsection{Community surveys}

The study comprised village surveys followed by field surveys. Surveys were co-ordinated through the OTML Community Relations Department. The department has established mutually agreed consultation protocols with communities for projects that require their engagement. Villagers are under no obligation to consent to surveys.

When the first village survey was planned (late 2008) the implementation of large-scale rehabilitation at Bige was imminent (planned for early 2009). The key objective therefore was to capture as much information as possible about the plants regarded as important to the affected communities rather than create an exhaustive inventory. Based on the interest generated and the diversity of information obtained, the authors are satisfied that sufficient information was captured to meet the desired project outcomes. The amount and quality of the data collected exceeded original expectations.

No emphasis was placed on specifically collecting plants of monetary value. This allowed the inclusion of plants used in traditional storytelling, ceremony and custom to be included.

\subsubsection{Village surveys}

The village surveys were conducted in September 2008 by staff from NRA and OTML with the assistance of Pastor Philip Beng (a Miamrae village elder). Village surveys were to be conducted by free listing (a data gathering method that involves asking individual respondents to list all the useful plants known to them, 
usually over several survey events (see Quinlan, 2005)). However, due to the high level of interest from villagers, participant availability and time limitations, this method of consultation could not be used. Instead, open or semi-structured group interviews were held with all interested village members. Participants from each village were split up into male and female groups.

\subsubsection{Field surveys}

Walk-in-the-woods surveys were conducted in September 2008, July 2009 and November 2009 by staff from NRA and OTML, assisted by Pastor Philip Beng. A Papua New Guinean botanist assisted in the first and third field excursions and liaised with the Papua New Guinea Forest Research Institute's Lae Herbarium for plant identification. Field surveys were used to identify plants mentioned in village surveys where possible.

The field survey involved walking through the lands of the accompanying villagers. Plant specimens were collected for identification as they were encountered. Not all the plants recorded during the village surveys were sighted during the field surveys. Where only an Awin name is available the lack of an accurate taxonomic identification will not prevent the inclusion of these plants in rehabilitation planting. New species were encountered and recorded during field surveys that were not recorded during village surveys.

During field surveys, the accompanying landholders were asked about their perceptions on land capability, particularly how they viewed the potential productivity of the Bige stockpiles. They were also asked about their knowledge of indicators of forest regeneration and whether they recognise particular forest attributes that indicate maturity or determine whether an abandoned garden had been fallow for long enough for it to be re-cleared for use as a garden again. Information was also collected on specific vegetation management practices used on cleared land that may affect its regeneration.

\subsection{Data interpretation and utilisation}

\subsubsection{Selection of plants for a priority rehabilitation planting list}

A Multi Criteria Analysis (MCA) approach was used to rank useful plants and to develop a priority rehabilitation planting list for Bige. This involved scoring plants according to their cultural value (as determined by a Cultural Significance Index (CSI)), ease of production and adaptation to site conditions. This allowed the selection of high cultural value species with a high certainty of successful propagation and survival.

The method used to derive the CSI is described in Section 2.3.1.1. Ease of propagation scores were based on professional experience or literature sources, or inferred from knowledge/behaviour of closely related species. Site tolerance scores were based on known habitat preferences and data from OTML internal reports and consultant observations on species colonise stockpiles or mine waste (NRA, 2011).

\subsubsection{Cultural significance index}

Many methods are available for assessing the relative value of particular plants to user communities (Hoffman and Gallaher, 2007). The CSI method of da Silva et al. (2006) was chosen for this assessment as it has a number of attributes that make it particularly appropriate for use with the Awin at Bige namely:

- Scoring is influenced by the number of different uses for each plant, but allows the significance of each use to be evaluated separately.

- The method limits the extent of researcher subjective weighting in the assessment.

- It gives weight to species that are actively managed by the community (relevant given the low intensity cultivation practices used by Awin communities near Bige).

- Scoring is not strongly influenced by economic or material value and can be applied to products important in customary use. 
- Scoring is influenced by informant consensus, thus improving the score of plants that are known to all communities and reducing sensitivity to sampling intensity (Hoffman and Gallaher, 2007).

The method of da Silva et al. (2006) was modified slightly to suit the nature of the data collected.

$$
\mathrm{CSI}=\sum(i \times e \times c) \times \mathrm{CF}
$$

Where:

species management score. A value (score) of 2 is given to species that are actively cultivated, managed or manipulated in any way and a value of 1 is given to species that are not managed.

e $\quad=\quad$ use preference score. A value of 2 is given to species that are known to be preferred for a given purpose, and a value of 1 is given to other species that may be used, but are not chosen preferentially for that purpose. For this assessment a value of 2 was given to a species for each use unless informants specifically identified it as being less preferred or of secondary importance for this use.

use frequency score. A value of 2 is given to well-known or frequently used plants, and a value of 1 given to plants that are rarely cited. In this assessment, a value of 1 has been given to plants that were recorded as being known to only a few informants or plants which are obsolete or their use is in decline. For example, informants stated that some medicinal plants (e.g. dei Taetae - Myristica subalulata, for coughs and colds) were gradually being replaced by imported pharmaceuticals and the making of sago bags from plant resources (e.g. Yawun - Spathoglottis papuana var. purbeculata) is in decline as they were being replaced with recycled rice bags.

$\mathrm{CF}=\quad$ correction factor. In da Silva et al. (2006), this was calculated as the number of citations for a given species over the number of citations for the most mentioned species. In this study, each village is treated as a single informant and the CF was calculated as the number of villages from which a plant use was recorded divided by the number of villages recording the use of the most popular plants (in this case 4).

Where a plant has multiple uses, $(i \times e \times c)$ is calculated for each use and these scores are summed. The selection of use categories in itself can influence the outcome of the CSI. As recommended by Hoffman and Gallaher (2007), use categories have been based on both researcher and informant defined divisions. The groupings selected (structural, canoe building, food, game animal feeding plants, medicinal and miscellaneous uses) are similar to those used by others (e.g. Phillips and Gentry, 1993; Gausset, 2004; Reyes-Garcia et al., 2006; Hoffman and Gallaher, 2007), but reflect local culturally important uses. For example, canoe building use is noted as a discrete group because of the importance of waterways in the society. Game animal feeding plants are also locally important (Maunsell, 1982).

\subsubsection{Multi-criteria analysis}

Table 1 provides details of how plants were scored according to each of the MCA attributes.

Potentially useful species were grouped into pioneer and early successional plants (referred to as Group 1 and Group 2 species in OTML, 2009) or late successional or poorly understood plants (usually mature forest species and referred to as Group 3 species in OTML, 2009). Group 1 and 2 species will be used for mass propagation whilst Group 3 species will have smaller production volumes and be introduced to increase diversity after the formation of a canopy cover (OTML, 2009). 
Table 1 MCA scoring structure

\begin{tabular}{|c|c|c|}
\hline Attribute & Score & Definition \\
\hline \multirow[t]{4}{*}{ Cultural value } & 3 & $\begin{array}{l}\text { High. Plants with a CSI equal to or greater than } 3 \text {. This CSI includes all } \\
\text { managed plants known to more than one village }\end{array}$ \\
\hline & 2 & $\begin{array}{l}\text { Moderate. Plants with a CSI equal to or greater than } 1.5 \text { and less than } 3 \text {. } \\
\text { The median CSI of all plants was } 1.5 \text {, therefore plants ranked } 2 \text { or } 3 \\
\text { include the most valuable } 50 \% \text { of plants recorded }\end{array}$ \\
\hline & 1 & Low. Plants with a CSI less than 1.5 \\
\hline & 0 & $\begin{array}{l}\text { Unknown. No ethnobotanical data collected and no CSI calculated. This } \\
\text { includes potentially useful rehabilitation plants known from previous } \\
\text { vegetation surveys, but were not recorded in the ethnobotanical surveys }\end{array}$ \\
\hline \multirow[t]{4}{*}{$\begin{array}{l}\text { Tolerance of open } \\
\text { and or degraded } \\
\text { conditions }\end{array}$} & 3 & $\begin{array}{l}\text { High. Plants with known or inferred high tolerance of open or degraded } \\
\text { conditions and/or proven ability to colonise mine wastes in the lower Ok } \\
\text { Tedi }\end{array}$ \\
\hline & 2 & $\begin{array}{l}\text { Moderate. Plants with known or inferred moderate tolerance of open or } \\
\text { degraded conditions }\end{array}$ \\
\hline & 1 & $\begin{array}{l}\text { Low. Plants with known or inferred low tolerance of open or degraded } \\
\text { conditions }\end{array}$ \\
\hline & 0 & $\begin{array}{l}\text { Unknown. Plants for which tolerance of open or degraded conditions is } \\
\text { unknown }\end{array}$ \\
\hline \multirow[t]{4}{*}{$\begin{array}{l}\text { Ease and reliability of } \\
\text { nursery propagation }\end{array}$} & 3 & $\begin{array}{l}\text { High. Plants known or inferred to be easy to successfully propagate and } \\
\text { grow in the nursery }\end{array}$ \\
\hline & 2 & $\begin{array}{l}\text { Moderate. Plants known or inferred to be moderately easy to successfully } \\
\text { propagate and grow in the nursery }\end{array}$ \\
\hline & 1 & $\begin{array}{l}\text { Low. Plants known or inferred to be difficult to propagate and grow } \\
\text { successfully in the nursery }\end{array}$ \\
\hline & 0 & Unknown. Plants for which propagation behaviour is unknown \\
\hline
\end{tabular}

The MCA ranking calculation differs between the lists to reflect the differences in the attributes of the plants in the two lists. The MCA scores were calculated as follows.

$$
\begin{aligned}
& \text { MCA score (Group } 1 \text { and } 2)=\text { cultural value score }+ \text { tolerance score }+ \text { propagation score } \\
& \text { MCA score }(\text { Group } 3)=\text { cultural value score }+ \text { propagation score }
\end{aligned}
$$

The priority planting lists were sorted according to the MCA score. Plants with the same MCA score were further sorted by whether they have been recorded in previous surveys of mine waste affected areas (stockpiles or dieback areas), then by CSI score.

\section{$3 \quad$ Results and discussion}

\subsection{Ethnobotany}

\subsubsection{General observations}

Thirtytwo men and forty women participated in the village or field surveys. There appeared to be several plants of which only women had knowledge. However, there was no taboo associated with this knowledge and its use and dissemination was not forbidden by the women. They expressed a strong desire for this 
knowledge to be preserved and passed on to future generations. A book containing much of the ethnobotanical knowledge collected during surveys has thus been produced and distributed to the villages that took part in the surveys (Toh and Butler, 2011).

Informant age ranged from 16 to 84 years old with a median of 35 years old. Although no specific data were collected, it appeared that older informants were able to provide more knowledge than younger ones; this age-contingent contraction of ethnobotanical knowledge is common in most rural communities (written comm., Dr Robert Voeks, December 2010) and these results may reflect a loss of knowledge across generations.

A significant number of villagers in the study area find employment with OTML and this and compensation payments are the principal source of income. Although the four villages visited during the surveys had buildings that contained modern materials such as corrugated iron and occasionally steel posts, the majority of houses were almost entirely constructed from locally sourced forest materials. Shop bought foods and household items are now common, but forest plant and animal resources are still actively collected.

The plant classification hierarchy of the Awin appeared to be similar to that of the Wopkaimin reported by Maunsell (1982) and Sillitoe (1995) where the highest level of division is associated with life form (tree, vine, etc.), followed by a well-populated middle division comprising genera/species and the lowest division comprising species or varieties. For very important plants, such as the sago palm (Metroxylon sagu), the Awin differentiate the classification to a finer scale than Linnaean species level. Only one sago palm species, Metroxylon sagu, is recognised as native to PNG (Rauwerdink, 1986; Flach, 1997; Kjær et al., 2004), while the Awin recognise at least 11 sago types/varieties. Most of the locally recognised sago palm types are prefixed with 'da'. The Awin recognised varieties based on morphological features such as armature, leaf quality (for thatching), stem patterns and perceived starch content. During rehabilitation it will be important to recognise that different varieties have different uses. Sago is clearly one of the most important cultural species in the area and close cooperation between local communities and OTML will be necessary to ensure planting material from desirable varieties is used in the rehabilitation effort.

\subsubsection{Ethnobotanical data}

A total of 190 locally used species or locally recognised plant types representing 62 families were recorded during the study, but this is only a fraction of the plants likely known and used. The online Plants of Papua New Guinea electronic database (http://www.pngplants.org/PNGdatabase) reports close to 400 unique species from the vicinity of Kiunga (the nearest well collected locality with a similar flora to Bige), of which only about 30 were recorded during this study.

The survey results greatly increased the documented ethnobotanical knowledge of the Awin. A pre-mining study largely focussed on the Wopkaimin clans near the mine pit and Tabubil Township on the upper Ok Tedi (Maunsell, 1982). Less detailed work was carried out on the Awin, with surveys conducted only in the vicinity of Kiunga (see Figure 1), not the affected villages near Bige. Maunsell (1982) recorded approximately 30 species as being used by the Awin, though the authors acknowledged that more plants were probably used than those recorded. Approximately $60 \%$ of the plants recorded in Maunsell (1982) as being used around Kiunga were also recorded in the current study around Bige. The high proportion of similarity is encouraging and indicates that a good core of commonly used or important plants has been identified.

Table 2 provides a breakdown of the number of plants recorded under each use category. Note that some plants appear in more than one use category. Da (Metroxylon sagu - sago palm) for example is a multipurpose plant that provides many services. Informants recognised specific varieties of sago to be better for a particular purpose (starch production, weaving of roofing shingles or for cutting down to allow edible larvae to colonise thus providing a food source or attracting pigs or ducks for hunting. All varieties have been assessed as one plant for this study, but further work to determine the CSI of individual varieties is recommended. 
Table 2 Summary of plants recorded in each use category

Main Use Category

No. of Plants in

Each Category

Structural (house post and structural timbers, roofing, walls, flooring, shutters, lashings)

47

Food (staples, vegetables, spices, fruits, nuts/kernels, mushroom and edible larval hosts)

Game hunting plants (habitat trees or plants that attract game animals that are hunted)

Canoe building (hulls, paddles and lashings)

Medicinal (internal and external infections and ailments, coughs, chronic illness

associated with possession by spirits, child development, birth control and women's

health, parasites, snake bite, tonics and journey wards)

Miscellaneous uses (billum, mat and basket making, lighting, cooking utensils, tools, hunting and weapons and traps, custom, hygiene, firewood)

\subsubsection{Cultural significance index}

Twenty two species were recorded as being actively planted and 17 species were actively retained when land was cleared for making gardens. These data were used to provide a value for factor $i$ in equation 1 for calculating CSI.

Calculated CSI values ranged from 0.25 to 32 for multiple use plants that are actively managed and used by all villages. The plants with the top $10 \mathrm{CSI}$ values are presented in Table 3. Several of these would be regarded as 'cultural keystone species' (Garibaldi and Turner, 2004) i.e. multiple use plants strongly associated with cultural life and largely irreplaceable (such as da varieties - Metroxylon sagu, dei Yei varieties - Pometia pinnata, dei Dengun - Gnetum gnemon, and Hmen - Hydriastele costata). Palms (ARECACEAE) stand out as a family with many high value member species.

\section{Table 3 Species with the highest CSI scores ranked in descending order}

\begin{tabular}{|c|c|c|c|c|c|}
\hline Family & Botanical Name & Awin Name & Number of Uses & Village Tally & CSI \\
\hline Arecaceae & Metroxylon sagu & da varieties & 4 & 4 & 32 \\
\hline Sapindaceae & Pometia pinnata & dei Yei varieties & 4 & 4 & 32 \\
\hline Dipterocarpaceae & Vatica rassak & dei Thwan & 4 & 4 & 28 \\
\hline Arecaceae & Hydriastele costata & Hmen & 4 & 4 & 24 \\
\hline Gnetaceae & Gnetum gnemon & dei Dengun & 3 & 4 & 24 \\
\hline Moraceae & Artocarpus communis & dei Wone & 3 & 3 & 18 \\
\hline Combretaceae & Terminalia kaernbachii & dei Haewe & 2 & 4 & 16 \\
\hline Malvaceae & Abelmoschus manihot & Mawoi & 2 & 4 & 16 \\
\hline Arecaceae & $\begin{array}{l}\text { Rhopaloblaste } \\
\text { ledermanniana }\end{array}$ & Sare & 3 & 3 & 15 \\
\hline Arecaceae & Unidentified black palm & Hmya & 2 & 4 & 12 \\
\hline
\end{tabular}

It is important to note that individual species may have more than one use at any one time. These uses all have relative values, depending on the needs of the landowner at that time. The value of a particular individual plant depends on the services that individual is capable of providing at the present time. Therefore, the future ability to bear valuable fruits would not necessarily prevent a sapling from being cut 
down for a more immediate use. Likewise, a tree with medicinal bark may be ring barked (killing the tree) in the process of obtaining the curative.

This demonstrates the importance to the landholder of the diversity intrinsic in the forest community as a whole. At any moment in time landholders may meet their thirst, hunger, building resource or medicinal needs from a variety of plants. Although several species may be recognised as being most suitable for a specific purpose, there are generally alternative species or individuals available. For landholders, not only is the presence of particular plants necessary, but species diversity is required to ensure useful plants can be sourced on an as-needs basis.

\subsection{Selection of plants for a priority rehabilitation planting list}

The CSI scores were used in the MCA to prioritise species that may be used in rehabilitation either through direct seeding or through the propagation of nursery seedlings. Selected priority species from Groups 1 and 2 , and Group 3 species are presented in Tables 4 and 5 . Priority status will not be the only criterion used to select planting material (NRA, 2011), but it is a useful guide for seed and wildling collection.

Table 4 Examples of priority Group 1 and 2 species to be selected for planting

\begin{tabular}{|c|c|c|c|c|c|c|}
\hline Family & Species & Awin Name & $\begin{array}{l}\text { Cultural } \\
\text { Score }\end{array}$ & $\begin{array}{l}\text { Tolerance } \\
\text { Score }\end{array}$ & $\begin{array}{l}\text { Propagation } \\
\text { Score }\end{array}$ & $\begin{array}{l}\text { Total } \\
\text { Score }\end{array}$ \\
\hline Arecaceae & $\begin{array}{l}\text { Metroxylon } \\
\text { sagu }\end{array}$ & da varieties & 3 & 3 & 3 & $\underline{9}$ \\
\hline Sapindaceae & $\begin{array}{l}\text { Pometia } \\
\text { pinnata }\end{array}$ & $\begin{array}{l}\text { dei Yei } \\
\text { varieties }\end{array}$ & 3 & 3 & 3 & $\underline{9}$ \\
\hline Moraceae & $\begin{array}{l}\text { Artocarpus } \\
\text { communis }\end{array}$ & dei Wone & 3 & 3 & 3 & $\underline{9}$ \\
\hline Combretaceae & $\begin{array}{l}\text { Terminalia } \\
\text { kaernbachii }\end{array}$ & dei Haewe & 3 & 3 & 3 & $\underline{9}$ \\
\hline Moraceae & Ficus sp. & $\begin{array}{l}\text { dei } \\
\text { Taii/Tkine }\end{array}$ & 3 & 3 & 3 & $\underline{9}$ \\
\hline Euphorbiaceae & $\begin{array}{l}\text { Glochidion } \\
\text { insectum }\end{array}$ & dei Kwete & 3 & 3 & 3 & $\underline{9}$ \\
\hline Dipterocarpaceae & Vatica rassak & dei Thwan & 3 & 3 & 3 & 9 \\
\hline Gnetaceae & $\begin{array}{l}\text { Gnetum } \\
\text { gnemom }\end{array}$ & dei Dengun & 3 & 3 & 3 & 9 \\
\hline
\end{tabular}

Underlined values indicate species (or closely related species) have been recorded as colonising or surviving on mine waste affected areas including the old stockpiles.

\subsection{Indigenous perceptions of land capability}

Local landowners clearly recognised a difference in the quality of the dredge sand being deposited on the stockpiles at Bige and the naturally occurring surrounding soils. The dredge sand is perceived to be poor for growing whereas the alluvial soils present along minor tributaries of the Ok Tedi (and occurring along the banks of the Ok Tedi before mine waste impacts) are perceived as very good soil for planting.

This is an important observation and it is true that the dredge sands are unlikely to be particularly productive if traditional swidden agricultural management methods are used. The sands will have low nutrient retention capacity and any fertility built up through litter incorporation during rehabilitation would be quickly turned over and lost following clearing. The fact that indigenous landholders recognise the poor capability of the land for agricultural use is important. If this knowledge is retained across generations, it 
may limit the degree of significant disturbance that occurs, which would be beneficial for long term erosion prevention. This does not mean the land cannot be used for the collection of forest resources in a traditional manner, but that its management must be appropriate to its capability and rehabilitation aims.

Table 5 Examples of priority Group 3 species to be selected for planting

\begin{tabular}{|c|c|c|c|c|c|}
\hline Family & Species & Awin Name & $\begin{array}{l}\text { Cultural } \\
\text { Score }\end{array}$ & $\begin{array}{l}\text { Propagation } \\
\text { Score }\end{array}$ & Total Score \\
\hline Clusiaceae & Calophyllum laticostatum & dei Gii Dupe & 3 & 3 & 6 \\
\hline Arecaceae & Hydriastele macrospadix & Tmoi & 3 & 3 & 6 \\
\hline Sapotaceae & Pouteria maclayana & dei Kosai & 3 & 3 & 6 \\
\hline Clusiaceae & Calophyllum sp. & $\begin{array}{l}\text { dei Gii } \\
\text { Wowo }\end{array}$ & 3 & 3 & 6 \\
\hline Myristicaceae & $\begin{array}{l}\text { Myristica fatua. var. } \\
\text { papuana }\end{array}$ & dei Swaiem & 3 & 2 & $\underline{5}$ \\
\hline Theaceae & Gordonia papuana & dei Hyim & 3 & 2 & 5 \\
\hline Cycadaceae & Cycas scratchleyana & Gaisa & 3 & 2 & 5 \\
\hline Tiliaceae & Microcos sp. & dei Smike & 3 & 2 & 5 \\
\hline
\end{tabular}

Underlined values indicate species (or closely related species) have been recorded as colonising or surviving on mine waste affected areas including the old stockpiles.

It is understood that OTML intends to or has set up an endowment trust fund for the communities whose land is impacted by the stockpiles (Shannon Mackenzie, 28 September 2009, written comm.). This fund will be held in perpetuity and has been designed to provide an income stream linked to the ongoing management of the stockpile revegetation. For the endowment fund to be effective in the long-term, it will be important for OTML to carefully disseminate information (particularly to younger members of the affected communities) about the poor long-term productivity potential of the land and the need to retain the revegetation cover into the future.

\subsection{Indigenous indicators of forest regeneration}

The cultivation of gardens represents a significant historic and ongoing cause of disturbance in the local environment. This disturbance is carried out on a shifting basis because local landowners recognise that continual use of any single site is generally unsustainable (within traditional low/no input land management practices). It was hoped that local communities may recognise particular phases of forest regeneration (and ultimately acceptable maturity) identifiable by particular attributes, such as structure or the emergence of particular species for example. It was hoped that if local landholders recognised such phases and that the attributes that characterise them could be measured in a scientifically reproducible way, this might provide a suitable trajectory against which rehabilitation progression could be compared. The use of measures for assessing rehabilitation progression and ultimately success based on indigenous knowledge was regarded as being more tangible to background landholders than the use of the 'standard' technical indicators found in the scientific literature or company closure documents.

In discussions, these hopes did not materialise into a distinct set of indicators that could be used to measure regeneration progression. This may have been as much due to difficulties in trying to communicate the concept as to the lack of such a system in the indigenous knowledge base. Nevertheless, relevant land management information was gathered.

Allen et al. (2002) noted that fallow vegetation in the study area is generally more than 30 years old. During the community consultations, discussions regarding garden usage indicated that informants recognised that land used for making a garden needed to lie fallow for a long period prior to re-use as a garden 
because "plants suck the ground [of goodness]". This period was not quantified but appears to be a minimum of 20 to 30 years as estimated by the following paraphrased comments:

"The soil is easy to dig [when first cleared] but goes hard after five years" and the landholder will need to "wait till the soil goes soft again [before making a new garden at that site]."

"When the plants that were originally planted die, then the land will be ready to come back to." (Note: planted species include dei Wone (Artocarpus communis), kho varieties (Pandanus conoideus) and dei Haewe (Terminalia kaernbachii), which may persist for 20 to 30 years).

"Gardens are made [on a particular patch of land] no more than once per generation."

During field visits, regrowth estimated to be approximately 60 year old forest (used as gardens over two generations previously) was 'ready' to be re-cleared according to landholders.

\subsection{Interpretation of indigenous knowledge for the development of completion criteria}

\subsubsection{Plant cultural value}

One of the reasons for conducting the survey was to address a primary objective of the rehabilitation program; namely, to provide a plant community that provides a range of goods and services that give the rehabilitated landform an intrinsic value to background landholders. An important long-term measure of the success of the rehabilitation program will therefore be the degree to which such value has been incorporated into the resulting plant community. Although the work carried out has identified rehabilitation species of cultural value, the dynamic nature of plant community succession and development means it is not possible to nominate how many or which exact species should be retained long-term. Such expectations will need to be managed in the early stages of rehabilitation. There is no guarantee that the species planted will survive through to maturity. The completion criteria chosen consider success will be reflected in a progressive trajectory of plant community development. Success will be demonstrated by an increasing and possible plateauing of species richness (a reflection of diversity, which is critical to traditional forest usage patterns) and prominence of culturally valued plants. This trajectory mimics patterns of natural forest regeneration, with rapid development in the early phases followed by a slowing in the rate of change as the community stabilises and matures.

\subsubsection{Landscape and plant community attributes}

The indigenous definitions of landscape and vegetation attributes in Section 3.4 are broad, but their basis is supported by scientific literature. In order to use the information, it has been necessary to redefine these indicators in a way that can be easily measured across a timeframe that is practical for a post-mining monitoring program.

Although Bourke and Harwood (2009) recognise that local land management practices include fallow cycles of longer than 15 years, the scientific literature suggests that after a period of about 15 years, landscape attributes in revegetated areas are beginning to stabilise or return to conditions within the range expected in unaffected areas. There is evidence that accumulation of soil carbon (a measure of organic matter content and a key element of soil chemical and physical fertility) in rehabilitating soil is most rapid in the first 10 to 15 years of system recovery, followed by a slowing of the rate of increase. Macedo et al. (2008) and Boddey et al. (2009) provide examples of reforestation based on leguminous trees (including Acacia spp.) that demonstrate soil nitrogen and carbon accumulation equivalent to undisturbed soils in 13 years. Tibbett (2008) cites similar results after 14 years. Gould (2011) documents rapid post-mining vegetation growth for five to eight years followed by a slowing approaching an asymptote in mean height after approximately 15 years. It is expected however that full equilibrium, when biomass synthesis and organic residue mineralisation are balanced, may take 25 to 50 years (Ahn, 1993; Schwenke et al., 2000; Rosser, 2008). This relates closely to the time period associated with one or two generations. It is considered that the adoption of such a long monitoring period before successful completion can be determined is 
impractical and that much of the important change would be captured in the first 15 years of monitoring. OTML (2009) has therefore adopted a 15 year monitoring and validation period for key completion criteria.

The indigenous indicator relating to the death of trees planted into abandoned gardens fits well with ecological succession theory. The plants introduced into gardens require open, sunny conditions to thrive. As recolonisation occurs in the abandoned gardens, a canopy develops and light conditions change. This change in light conditions eventually leads to the decline of the early colonisers, instead favouring the growth of more light sensitive tree seedlings that gradually replace them. Vegetation surveys will be able to determine the dynamics of community development and it will be possible to monitor the fate of trees originally planted into rehabilitation areas. The increasing dominance of late successional species would for example indicate that pioneer trees were in relative decline.

The build-up of soil organic matter and the associated increase in biological activity and bioturbation over time would be expected to improve soil physical conditions by increasing soil structural development and reducing soil density (i.e. the soil would become 'softer' and more friable/workable). It is possible to measure changes in bulk density and organic matter content as a surrogate for workability.

\subsection{Bige completion criteria}

The basis for the development of the completion criteria adopted for rehabilitation at Bige is presented in OTML (2009) with a full list of completion criteria. Table 6 outlines the completion criteria that specifically address indigenous measures of the return of forest function or community needs and forest usage patterns.

\section{Conclusions}

This study has demonstrated that indigenous knowledge can be effectively incorporated into rehabilitation planning. At Ok Tedi this cultural exchange has been successful in igniting interest amongst landowners about rehabilitation outcomes. This engagement is necessary for long term rehabilitation success and should increase the likelihood of rehabilitation goals being accepted.

Nevertheless, it will be necessary to maintain dialogue with landholders as rehabilitation progresses regarding land capability, rehabilitation aims and changing cultural values. Change management has been built into the planning to allow information of cultural value to be updated to meet the needs of the next generation of landowners.

Indigenous knowledge has also been successfully used to develop culturally appropriate completion criteria. The project was unable to collect detailed information on landholders' knowledge of the stages of regrowth that could have been adopted as benchmarks for rehabilitation progression. The possibility of developing such benchmarks (which could be developed and applied to other projects) warrants further research.

Indigenous knowledge is being lost in many communities globally. There is an opportunity for mining companies to contribute to the preservation of this knowledge in the communities they operate in.

\section{Acknowledgements}

We acknowledge the people of Bige, Kwiape, Miamrae and Senamrae for sharing their wealth of traditional knowledge and customs. Pastor Philip Beng deserves particular mention for liaising with villagers. The assistance of the following OTML Environment Department staff (present and past) is gratefully acknowledged: Clara Nanuk, Andy Ikuavi, Richard Asipali, Bernadette Williams, Dr Michael Ridd and Jim Veness. Staff of the Community Relations Department assisted in notifying villages and the assistance of Jimmy Kambare (also a Bige village leader) and the encouragement of Dr Monica Rau in particular is acknowledged. Olo Gebia provided invaluable assistance in the field and with plant specimen identification. The Lae Herbarium's facilities were extensively used and this assistance is acknowledged. The herbarium's Kipiro Damas reviewed many of the plant IDs for botanical accuracy and with thank him for his valuable 
input. Finally, we thank Dr Robert Voeks (California State University, Fullerton, USA) for providing encouragement in the early stages of the project and for reviewing our work. This work was commissioned by OTML.

\section{Table 6 Bige completion criteria developed to include indigenous knowledge}

\begin{tabular}{|c|c|c|}
\hline $\begin{array}{l}\text { Indigenous Indicator of Returned Function or } \\
\text { Desired Attribute }\end{array}$ & Completion Criteria Adopted & Monitoring Variable \\
\hline Soil becomes soft and friable & $\begin{array}{l}\text { A progressive increase in Soil } \\
\text { Organic Matter (SOM) during } \\
\text { the adopted monitoring and } \\
\text { validation period }\end{array}$ & $\begin{array}{l}\text { SOM measured as } \% \\
\text { organic carbon }\end{array}$ \\
\hline Soil becomes soft and friable & $\begin{array}{l}\text { A progressive decrease in the } \\
\text { dry bulk density of surface } \\
\text { soil during the adopted } \\
\text { monitoring and validation } \\
\text { period }\end{array}$ & $\begin{array}{l}\text { Dry bulk } \\
\text { density/porosity }\end{array}$ \\
\hline $\begin{array}{l}\text { Diversity of species provides an ongoing } \\
\text { diversity of products available on a needs basis. } \\
\text { This addresses the nature of forest usage by } \\
\text { the Awin }\end{array}$ & $\begin{array}{l}\text { A progressive increase or } \\
\text { stabilisation }{ }^{1} \text { in the diversity } \\
\text { of species during adopted } \\
\text { monitoring and validation } \\
\text { period }\end{array}$ & $\begin{array}{l}\text { Total number of } \\
\text { species }\end{array}$ \\
\hline $\begin{array}{l}\text { Trees originally planted into an abandoned } \\
\text { garden die out. } \\
\text { (Note: an increase in the proportion of Group } 3 \\
\text { [late successional] species would imply that } \\
\text { early successional species tolerant of open } \\
\text { conditions - such as those planted into gardens } \\
\text { - would be in decline) }\end{array}$ & $\begin{array}{l}\text { A progressive increase or } \\
\text { stabilisation }^{1} \text { in the proportion } \\
\text { of successional species }{ }^{2} \\
\text { (Group } 3 \text { ) since first recorded. } \\
\text { A progressive increase or } \\
\text { stabilisation }^{1} \text { in the proportion } \\
\text { of basal area represented by } \\
\text { successional species }{ }^{2} \text { since first } \\
\text { recorded }\end{array}$ & $\begin{array}{l}\text { Total number and } \\
\text { classification of } \\
\text { species } \\
\text { Basal area (trees and } \\
\text { shrubs over } 1 \mathrm{~m} \text { ) }\end{array}$ \\
\hline $\begin{array}{l}\text { Traditional land use includes the collection of } \\
\text { plants with high cultural value. The returned } \\
\text { plant community must provide at least a subset } \\
\text { of plants with high cultural value }{ }^{3} \text { to the Awin, } \\
\text { to achieve one of the key rehabilitation } \\
\text { objectives at Bige }\end{array}$ & $\begin{array}{l}\text { A progressive increase or } \\
\text { stabilisation }^{1} \text { in the proportion } \\
\text { of species designated to be of } \\
\text { high cultural value }{ }^{3} \text { since first } \\
\text { recorded }\end{array}$ & Presence/absence \\
\hline
\end{tabular}

Stabilisation in this context means plateauing (marked decrease in the rate of change) following an initial increase.

Interpreted in this context as late successional (old growth) species.

High cultural value in this context is defined as those species with a CSI of greater than or equal to 1.5 (the top $50 \%$ of plants ranked in this study) or equivalent to a cultural value score of 2 or 3 in the MCA (refer to Table 1).

\section{References}

Ahn, P.M. (1993) Tropical Soils and Fertiliser Use, Intermediate Tropical Agriculture Series, Longman Group.

Allen, B.J., Hide, R., Bourke, R.M., Akus, W., Fritsch, D., Grau, R., Ling, G. and Lowes, E. (2002) Western Province: Text Summaries, Maps, Code Lists and Village Identification, Agricultural Systems of Papua New Guinea Working Paper No. 4. Land Management Group, Department of Human Geography, Research School of Pacific and Asian Studies, Australian National University, Canberra. 
Boddey, R.M., Alves, B.J.R., de B. Soares, L.H., Jantalia, C.P and Urquiaga, S. (2009) Biological Nitrogen Fixation and the Mitigation of Greenhouse Gas Emissions. American Society of Agronomy, Nitrogen Fixation in Crop Production, D.W. Emerich and H.B. Krishnan (eds), Agronomy Monograph 52.

Bourke, R.M. and Harwood, T. (2009) Food and Agriculture in Papua New Guinea, ANU E Press, Australian National University, Canberra.

Carr, P.C. (2010) Settlement patterns at Ok Tedi - stakeholders, 'corner' settlers and invaders, in Proceedings Fifth International Conference on Mine Closure (Mine Closure 2010), A.B. Fourie, M. Tibbett and J. Wiertz (eds), 23-26 November 2010, Viña del Mar, Chile, Australian Centre for Geomechanics, Perth, pp. 199-204.

da Silva, V.A., Andrade, L. de H.C. and de Albuquerque, U.P. (2006) Revising the Cultural Significance Index: the case of the Fulni-ô in northeastern Brazil, Field methods 18, pp. 98-108.

Flach, M. (1997) Sago palm Metroxylon sagu Rottb.: Promoting the conservation and use of underutilized and neglected crops 13, Institute of Plant Genetics and Crop Plant Research, Gatersleben/International Plant Genetic Resources Institute, Rome, Italy.

Garibaldi, A. and Turner, N. (2004) Cultural Keystone Species: Implications for Ecological Conservation and Restoration, Ecology and Society online, Vol. 9 (3), pp. 1-18.

Gausset, Q. (2004) Ranking local tree needs and priorities through an interdisciplinary action research approach, Journal of Transdisciplinary Environmental Studies 3, pp. 1-17.

Gould, S.F. (2011) Comparison of post-mining rehabilitation with reference ecosystems in monsoonal Eucalypt woodlands, northern Australia, Restoration Ecology doi: 10.1111/j.1526-100X.2010.00757.x (published online).

Hoffman, B. and Gallaher, T. (2007) Importance indices in ethnobotany, Ethnobotany Research and Applications 5, pp. 201-218. ICMM (2008) Planning for Integrated Mine Closure: Toolkit, Published by the International Council on Mining and Metals.

Jackson, R. (1998) Report on the survey of lower Ok Tedi villages, May-June 1998, Internal report for Ok Tedi Mining Ltd: Mine Waste Management Project - Socio-Economic Monitoring.

Jackson, R. (2002) Capacity Building in Papua New Guinea for Community Maintenance During and after Mine Closure, MMSD Working Paper No. 181, Published by the International Institute for Environment and Development and the World Business Council for Sustainable Development, February 2002.

Kjær, A., Barfod, A.S., Asmussen, C.B. and Seberg, O. (2004) Investigation of genetic and morphological variation in the Sago Palm (Metroxylon sagu; Arecaceae) in Papua New Guinea, Annals of Botany 94, pp. 109-117.

Lamb, D. and Gilmour, D. (2003) Rehabilitation and Restoration of Degraded Forests, Published by IUCN and WWF.

Limpitlaw, D., Aken, M., Lodewijks, H. and Viljoen, J. (2005) Post-mining Rehabilitation, Land Use and Pollution at Collieries in South Africa, Presented at the Colloquium: Sustainable Development in the Life of Coal Mining, The South African Institute of Mining and Metallurgy, Boksburg, July 2005.

Macedo, M.O., Resende, A.S., Garcia, P.C., Boddey, R.M., Jantalia, C.P., Urquiaga, S., Campello, E.F.C. and Franco, A.A. (2008) Changes in soil $\mathrm{C}$ and $\mathrm{N}$ stocks and nutrient dynamics 13 years after recovery of degraded land using leguminous nitrogenfixing trees, Forest Ecology and Management 255, pp. 1516-1524.

Maunsell (1982) Ok Tedi Environmental Study, Report prepared by Maunsell \& Partners Pty Ltd for Ok Tedi Mining Ltd.

NRA (2009) Development of Bige Revegetation Program and Completion Criteria, Report prepared by NRA Environmental Consultants for Ok Tedi Mining Ltd, November 2009.

NRA (2011) Incorporating Indigenous Knowledge into Rehabilitation Planning at Ok Tedi Mining Ltd Bige Operations - East Bank Communities, Report prepared by NRA Environmental Consultants for Ok Tedi Mining Ltd, October 2011.

OTML (2006) OK Tedi Mining Ltd. Mine Waste Tailings Project Change Notice Supporting Document, OTML report, September 2006, http://www.oktedi.com/attachments/213_Main\%20Document_MWTPChangeNoticeSupportingDoc_08Sept06.pdf).

OTML (2007) OK Tedi Mining Ltd. Bige Closure Plan, Internal OTML report prepared by the Environment Department, June 2007.

OTML (2009) OK Tedi Mining Ltd. Mine Area Rehabilitation Plan, Report ENV091126, prepared by the Environment Department, Ok Tedi Mining Ltd (available at http://www.oktedi.com/images/stories/MineClosureSubmission/d\%201_marp.pdf).

Phillips, O. and Gentry, A. (1993) The useful plants of Tambopata, Peru: I. Statistical hypotheses tests with a new quantitative technique, Economic Botany 47, pp. 15-32.

Quinlan, M. (2005) Considerations for collecting freelists in the field: Examples from ethnobotany, Field Methods 17, pp. $219-234$.

Rauwerdink, J.B. (1986) An essay on Metroxylon, the sago palm. Principles 30, pp. 165-80.

Reyes-García, V., Huanca, T., Leonard, W., Vadez, V. and Wilkie, D. (2006) Cultural, practical and economic value of wild plants: A quantitative study in the Bolivian Amazon, Economic Botany 60, pp. 62-74.

Rosser, B. (2008) Soil recovery on landslide scars in erodible, Wairarapa siltstone hill country, Soil Horizons 17, Landcare Research New Zealand, November 2008.

Schwenke, G.D., Ayre, L., Mulligan, D.R. and Bell, L.C. (2000) Soil stripping and replacement for the rehabilitation of bauxite-mined land at Weipa, II: Soil organic matter dynamics in mine soil chronosequences, Australian Journal of Soil Research 38, pp. 371-393.

Smith, H.D. (2008) Using Traditional Ecological Knowledge to Develop Closure Criteria in Tropical Australia, in Proceedings Third International Seminar on Mine Closure (Mine Closure 2008), A.B. Fourie and M. Tibbett, I.M. Weiersbye, P. Dye (eds), 14-17 October 2008, Johannesburg, South Africa, Australian Centre for Geomechanics, Perth, pp. 47-56.

Smith, H.D. (2009) Strangers in a foreign land - developing cultural closure criteria for mines in Australia's Northern Territory, in Proceedings Fourth International Conference on Mine Closure (Mine Closure 2009), A.B. Fourie and M. Tibbett (eds), 9-11 September 2009, Perth, Australia, Australian Centre for Geomechanics, Perth, pp. 3-12. 
Sillitoe, P. (1995) An ethnobotanical account of the plant resources of the Wola region, southern highlands province, Papua New Guinea. Journal of Ethnobiology 15(2): 201-35.

Tibbett, M. (2008) Carbon Accumulation in Soils During Reforestation - The Australian Experience After Bauxite Mining, in Proceedings Third International Seminar on Mine Closure (Mine Closure 2008), A.B. Fourie and M. Tibbett, I.M. Weiersbye, P. Dye (eds), 14-17 October 2008, Johannesburg, South Africa, Australian Centre for Geomechanics, Perth, pp. 3-11.

Toh, I. and Butler, A. (2011) An introductory guide to the plants used by the Awin in Bige, Kwiape, Miamrae and Senamrae Western Province Papua New Guinea, Published by NRA Environmental Consultants, 156 p. 